DOI: https://doi.org/10.15407/kvt201.03.087

UDC 615.47: 004.9

VOVK M.I., PhD (Biology), Senior Researcher,

Head of Bioelectrical Control \& Medical Cybernetics Department

e-mail: vovk@irtc.org.ua; imvovk3940@gmail.com

KUTSIAK O.A., PhD (Engineering),

Senior Researcher of the Bioelectrical

Control \& Medical Cybernetics Department

e-mail: spirotech85@ukr.net

International Research and Training Center

for Information Technologies and Systems

of the NAS of Ukraine and of MES of Ukraine,

40, Acad. Glushkov av. Kyiv, 03187, Ukraine

\title{
INFORMATION TECHNOLOGY FOR FORMING A PERSONAL MOVEMENT REHABILITATION PLAN AFTER A STROKE
}

Introduction. Stroke ranks second in the list of major causes of death and is the leading cause of disability in Ukraine. Synthesis of innovative technologies that help to movement restoration after stroke is an urgent scientific and practical task.

The purpose of the paper is to synthesize the information technology for forming a personal movement rehabilitation plan after a stroke on the basis of quantitative assessment of movement deficit according to the evidence criteria.

Results. The technology for information support for forming a movement training personal plan to restore movements after a stroke has been developed. This technology is implemented by the specialized software module "MovementRehabStroke 1.0" for information and consulting support to the physician in determining the plan: movements, programs, movements training duration based on electromyostimulation and / or biofeedback.

The structural and functional model of the operator (physician) and software module "MovementRehabStroke 1.0" interaction has been developed. This module consists of a graphical interface and basic information modules: Database, Module "MovementTestStroke 1.1" for quantitative assessment of movement deficit and Module for forming the personal movement training plan. The interface provides the interactive mode of work with information modules for operator.

An algorithm has been developed for the operation of specialized software module "MovementRehabStroke 1.0" in researching on the formation of a personal training plan for patient movements based on indicators of quantitative assessment of movement deficit, which is provided by the information module "MovementTestStroke 1.1" and information received from a personal electronic medical record (EMR) of the patient: indicators of neurological status, concomitant diseases etc.

Conclusions. The obtained results will contribute to the creation of a new class of mobile means of digital medicine - mobile applications installed in the structure of the smartphones for movements assessment after a stroke, forming the personal rehabilitation plan, and assessment of rehabilitation results.

(c) VOVK M.I., KUTSIAK O.A., 2020 
Keywords: information technology, digital medicine, software modules, stroke, movements, diagnostics, rehabilitation, personal plan, structural and functional model, algorithm, electrical stimulation, biofeedback.

\section{INTRODUCTION}

Up to 150,000 strokes occur each year in Ukraine and more than 100,000 people die from cerebrovascular disease and stroke. This disease can cause disorders or loss of movements, vision, speech and mental functions. In addition, stroke dramatically increases the risk of dementia. Of particular concern the increase in stroke rates among people of working age: about a third of all strokes occur before the age of 60 and only a small proportion of stroke survivors return to work.

The World Health Organization (WHO) estimates that stroke events in EU countries are likely to increase by $30 \%$ between 2000 and 2025 [1]. In Europe the Stroke Action Plan 2018-2030 was approved.

The experience of many countries shows that quality care for stroke patients can significantly reduce the risk of premature death or acquired disability.

The relevance and social significance of scientific researches, which results are presented in the paper, are determined by the synthesis of innovative technologies, methods and means that contribute to the movements' rehabilitation after a stroke.

\section{PROBLEM STATEMENT}

The main purpose of the rehabilitation process is applying the methods and means that mobilize, launch and enhance patient's reserves, aimed at restoring the affected or lost functions adequately to their state at each rehabilitation stage taking into account the general patient's state, conco-mitant diseases etc. Stroke care should be a continuous sequence of individual treatment and rehabilitation measures up to the maximum restoration of affected or lost functions. Therefore, the movement deficit diagnostics after stroke at each rehabilitation stage, the use of methods and means for quantitative assessment of motor dysfunctions, which make it possible to perform an in-depth analysis, to identify the specifics and secondary prevention of motor dysfunctions as well as assessment of the effectiveness of rehabilitation, play an important role.

Quantitative assessment of movement deficit, which is built using modern intelligent information technologies (IIT) based on evidence criteria, plays an important role in digital medicine. This assessment supports the physician to reduce the error in assessing the course and effectiveness of rehabilitation process. And it is the basis for synthesis of the mobile means for information and consulting support the physician in formation and adjustment of personal plan for affected movements' restoration at each rehabilitation stage.

The quantitative assessment of hand movement deficit during purposeful find motor hand training to restore speech is of particular importance. It makes it possible to study and compare the restoration dynamics of affected fine motor hand movements with the restoration dynamics of speech in case of motor or motor-sensory aphasia after a stroke.

The clinical testing results of proposed new technique for quantitative assessment of movement deficit [2] in the study of their restoration dynamics by TRENAR $^{\circledR}$ technology became the basis for a specialized digital medicine's 
software module "MovementTestStroke 1.0" for movements diagnosing [3]. This module is made in the software environment Visual Studio 2013, programming language - C\#. It is installed in the PC structure [4].

The purpose of the paper is to synthesize the information technology for forming a personal movement rehabilitation plan after a stroke on the basis of quantitative assessment of movement deficit according to the evidence criteria.

\section{INFORMATION SUPPORT FOR FORMING A PERSONAL MOVEMENT REHABILITATION PLAN AFTER A STROKE}

Information support for forming the personal movements trainings plan with the purpose of their restoration is implemented by the specialized software module "MovementRehabStroke 1.0" for information and consulting support to the physician in forming such a plan: movements, programs and movements training duration, which is based on methods of electromyostimulation and / or biofeedback by "TRENAR" ${ }^{\circledR}$ technology. The basic factors in forming the personal movement training plan are informative indicators of quantitative assessment of movement deficit, muscle tone, which are determined by a specialized "MovementTestStroke 1.1" software module, as well as indicators of the patient's neurological status, information on concomitant diseases. These indicators determine the movements to be trained, their training duration, as well as the permission / limitation for training the forced muscle contractions by program electrical stimulation method or for training the voluntary contractions by biofeedback method.

The structural and functional model of interaction of the operator (physician) and specialized "MovementRehabStroke 1.0" software module for information and consulting support to the physician in forming the patient's personal movements training plan after a stroke is presented (Fig. 1).

The software module "MovementRehabStroke 1.0" consists of the graphical interface and the software module objects — the basic information units: I - Database, II - Module for quantitative assessment of movement deficit "MovementTestStroke 1.1", III - Module for forming the personal movement training plan (Fig. 1).

These information modules are designed as separated units with complete functionality and are directly connected with the graphical interface. The interface provides the interactive mode of work with information modules for operator. The software implementation of "MovementRehabStroke 1.0" is the Microsoft Visual Studio 2013 environment, C \# programming language. It is installed in the PC structure.

Information module I "Database" consists of two main components: "Patients list" and "Patient's account (personal electronic medical record)". It is designed to store the information about each patient who has already passed or is passing the rehabilitation for the first time.

The "Patients list" component contains a tabular list, in which each patient is represented by express information record (hospitalization date, patient's surname-initials-sex, medical record number, physician's surname).

The operator checks (1) on the interface the presence of the right patient in this list by the object-oriented programming (OOP) methods. In case of patient's absence the operator adds to this list patient's express information from the 
medical record according to standard - form 003/o "Medical card of the inpatient", and also inputs all information from this medical record (neurological status, concomitant diseases etc.) to Database's component "Patient's account".

The component "Patient's account" receives the specialized information:

- the prohibitions / limitations for movements training (e.g., acute period of illness, diabetes mellitus on decompensation, the artificial cardiac pacemaker presence, etc.), marked by the operator;

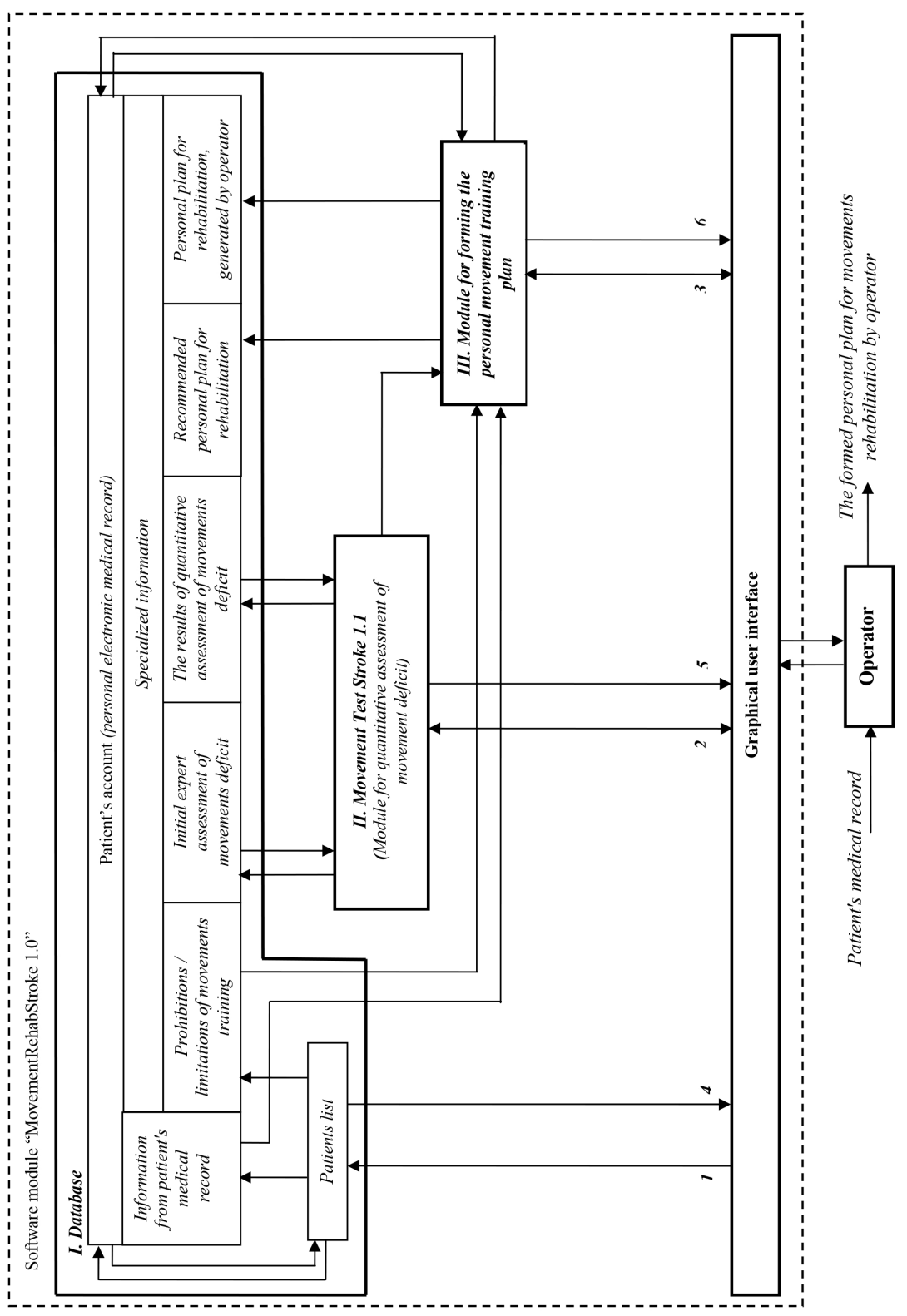

Fig. 1. Structural and functional model of interaction of the operator and software module "MovementRehabStroke 1.0". 1-6 markings are in the text 
- initial expert assessment of movements deficit and results of quantitative assessment of movement deficit before and after rehabilitation from information module II (Module for quantitative assessment of movement deficit);

- the personal plans for movements rehabilitation (recommended and generated by the operator) from the information module III (Module for forming the personal movement training plan). This information is also stored in relevant clusters of the Database's patient's personal electronic medical record (EMR).

At the request of the operator (1), the interface displays (4) complete information from the patient's personal EMR - information from the medical card and specialized information.

Information module II - Module for quantitative assessment of movements deficit "MovementTestStroke 1.1" contains tables for expert assessment of movements deficit of upper and lower limbs at the individual joints level according to the main evidence criteria (muscle strength, movement's volume) [5]; for assessment by additional evidential criteria of fine motor hand (contrasting the thumb, flexing the hand's fingers in fist, the hand's main motor function (capturing), the hand's fingers extension) [3, 6] (Table 1) and walking (walking shape); as well as for assessment of muscle hyper- or hypotone $[3,5,7]$ according to the Protocol for quantitative assessment of movements deficit of patient after a stroke [3].

The difference in fine motor hand assessment is in introduction of additional evidence criterion - the hand's fingers extension, which is important both for forming the personal plan of its training and to assess the fine motor hand restoration, associated with the speech restoration [8] according to the Table 1. These relevant changes are introduced in the previously developed Protocol [3]. It is this introduction of additional evidence criterion that differs the information module for quantitative assessment of movement deficit "MovementTestStroke 1.1" from the previously developed "MovementTestStroke" [3].

Expanding the criteria number for deficit assessment of affected hand supports the in-depth analysis of deficit. It is important for forming the personal fine motor hand training plan and for restoration of various aspects of its function, including speech restoration in case of motor or motor-sensory aphasia. Movement restoration of affected hand is of particular importance, after all most common deficit after a stroke is hemiparesis of contralateral upper limb, with more than $80 \%$ of stroke patients experiencing this condition acutely and more than $40 \%$ chronically [9].

The operator calls (2) on the interface the relevant expert assessment tables and performs with their application the initial expert assessment of patient's movement deficit according to the evidence criteria, expressed in points.

The operator receives (5) the results of quantitative assessment of patient's movement deficit (integrated quantitative assessment of the deficit, paresis degree, value and gradation of movement restoration efficiency) according to the OOP methods based on initial expert assessment from the information module II (Module for quantitative assessment of movement deficit).

The initial expert assessment and the results of quantitative assessment of movement deficit are stored EMR clusters ("Initial expert assessment of movements deficit" and "The results of quantitative assessment of movements deficit") in Database. 
Table 1. The fine motor hand assessment by criteria

\begin{tabular}{|c|c|c|c|c|}
\hline $\begin{array}{l}\text { Points / } \\
\text { Criterion }\end{array}$ & $\begin{array}{l}\text { Contrasting of } \\
\text { the thumb }\end{array}$ & $\begin{array}{l}\text { Flexion of the } \\
\text { hand's fingers } \\
\text { in fist }\end{array}$ & $\begin{array}{l}\text { The hand's main } \\
\text { motor function } \\
\text { (grasping and holding } \\
\text { objects) }\end{array}$ & $\begin{array}{l}\text { The hand's } \\
\text { fingers exten- } \\
\text { sion }\end{array}$ \\
\hline 5 & $\begin{array}{l}\text { Reaches the base } \\
\text { of all fingers }\end{array}$ & $\begin{array}{c}\text { Full fingers } \\
\text { flexion in formed } \\
\text { fist }\end{array}$ & $\begin{array}{l}\text { The main function is } \\
\text { saved completely }\end{array}$ & $\begin{array}{l}\text { Full fingers } \\
\text { extension }\end{array}$ \\
\hline 4 & $\begin{array}{l}\text { Reaches the base } \\
\text { of all fingers } \\
\text { (without holding } \\
\text { the base) }\end{array}$ & $\begin{array}{c}\text { Full fingers } \\
\text { flexion in } \\
\text { slightly opened } \\
\text { fist }\end{array}$ & $\begin{array}{l}\text { Grasping and holding } \\
\text { of big objects are } \\
\text { saved, grasping of } \\
\text { small objects (with no } \\
\text { hold function) is avail- } \\
\text { able }\end{array}$ & $\begin{array}{c}\text { Significant } \\
\text { fingers exten- } \\
\text { sion. The open } \\
\text { fist volume is } \\
75-90 \% \text { of the } \\
\text { norm. }\end{array}$ \\
\hline 3 & $\begin{array}{l}\text { Reaches the base } \\
\text { of fourth finger }\end{array}$ & $\begin{array}{l}\text { Limited fingers } \\
\text { flexion in mod- } \\
\text { erately opened } \\
\text { fist }\end{array}$ & $\begin{array}{l}\text { Grasping and holding } \\
\text { of big objects is } \\
\text { available, grasping of } \\
\text { small objects is com- } \\
\text { plicated }\end{array}$ & $\begin{array}{l}\text { Moderate } \\
\text { fingers exten- } \\
\text { sion. Hand is } \\
\text { in the half- } \\
\text { opened fist } \\
\text { form. }\end{array}$ \\
\hline 2 & $\begin{array}{l}\text { Reaches the base } \\
\text { of third finger }\end{array}$ & $\begin{array}{l}\text { Moderate fingers } \\
\text { flexion without } \\
\text { fist formation }\end{array}$ & $\begin{array}{l}\text { Grasping of big objects } \\
\text { without their long and } \\
\text { strong holding is avail- } \\
\text { able, grasping of small } \\
\text { objects is impossible }\end{array}$ & $\begin{array}{l}\text { Slight fingers } \\
\text { extension. } \\
\text { Hand is in the } \\
\text { slight-opened } \\
\text { fist form. } \\
\end{array}$ \\
\hline 1 & $\begin{array}{l}\text { Reaches the base } \\
\text { of second finger }\end{array}$ & $\begin{array}{l}\text { Slight fingers } \\
\text { flexion }\end{array}$ & $\begin{array}{l}\text { Grasping and holding } \\
\text { both big and small } \\
\text { objects are impossible; } \\
\text { the additional function } \\
\text { of supporting and } \\
\text { pressing the object is } \\
\text { saved }\end{array}$ & $\begin{array}{l}\text { Partial fingers } \\
\text { extension. } \\
\text { Hand is in the } \\
\text { closed fist } \\
\text { form. }\end{array}$ \\
\hline 0 & $\begin{array}{l}\text { Contrasting is } \\
\text { impossible }\end{array}$ & $\begin{array}{l}\text { No fingers flex- } \\
\text { ion }\end{array}$ & $\begin{array}{l}\text { Grasping and holding } \\
\text { both big and small } \\
\text { objects are impossible }\end{array}$ & $\begin{array}{l}\text { Fingers exten- } \\
\text { sion is impos- } \\
\text { sible. Hand is } \\
\text { in the closed } \\
\text { fist form. }\end{array}$ \\
\hline
\end{tabular}

Information module III "Module for forming the personal movement training plan" is designed for information and consulting support to the physician in forming the personal movements training plan, which is most effectively activates the additional reserves of the patient's organism to restore the movements.

This information module receives information on concomitant diseases, the emotional and volitional sphere state and prohibition / limitation factors of movements training from the relevant clusters of patient's EMR in Database, the initial expert assessment of movements deficit and the patient's paresis degree from module for quantitative assessment of movements deficit "MovementTestStroke 1.1".

This module contains OOP methods, which determine the permission / limitation / prohibition for movements training based on certain factors, and permitted movements, methods, programs and movements training duration based on the initial expert assessment of patient's movement deficit; adjust these indicators based on concomitant diseases and the emotional and volitional sphere state; distribute methods, programs, movements and their training duration by priority according to the relevant decision rules. 
Submitting the priority to method, training program comes from the principle of activating the additional reserves of organism for movement restoration at the current patient's rehabilitation stage. The priority for movement depends on motor disorders depth, but if patient has motor aphasia elements, then fine motor hand movements training gets a higher priority. The main factors of training duration are the patient's general condition, concomitant diseases, individual sensitivity to electrical stimulation, emotional and volitional sphere state etc.

The operator is issued (3) by notification and the patient's session ends in case of movements training complete prohibition factors are present in patient. In case of movements training limitations, the program continues to work with taking it into account.

The recommended personal rehabilitation plan according to priority of its components (methods, programs, movements and their training duration) is output for the operator on the interface (3) and also recorded in EMR cluster "Recommended personal rehabilitation plan" (Database).

The operator checks (3) the recommended personal plan and optionally calls up complete patient information, which is displayed (6) on the interface. Operator marks (3) in this plan concrete movements, programs and movement training duration, i.e. forms a personal plan for movements training at this rehabilitation stage. Using OOP methods, the personal plan is generated by the operator to the EMR cluster "Personal plan for rehabilitation, generated by operator" (Database) and also is displayed as a text file on the interface (6).

The operator begins training the patient's movements at certain rehabilitation stage according to generated personal rehabilitation plan. After completing the movement training sessions, the operator diagnoses the patient's movements and determines the rehabilitation effectiveness.

\section{ALgORITHM FOR FORMING A PERSONAL REHABILITATION PLAN}

Algorithm for operation of specialized software module "MovementRehabStroke 1.0 " for information and consulting support to the physician in researching for forming the patient's personal movements training plan based on expert and quantitative assessment of movements deficit, determined by specialized "MovementTestStroke 1.1" software module, with taking into account patient's neurological status, concomitant diseases, emotional and volitional sphere state etc. (Fig. 2).

According to the structural and functional model (Fig. 1), the module operation begins with loading the patients list, checking the presence of right patient in the list by the operator. If the list is not yet been created or no such patient exists, the operator inputs express information from that patient's medical record to create or update the patient list. At the same time, a personal electronic medical record (EMR) of the patient is created. After data input, the operator returns to the updated patients list. 


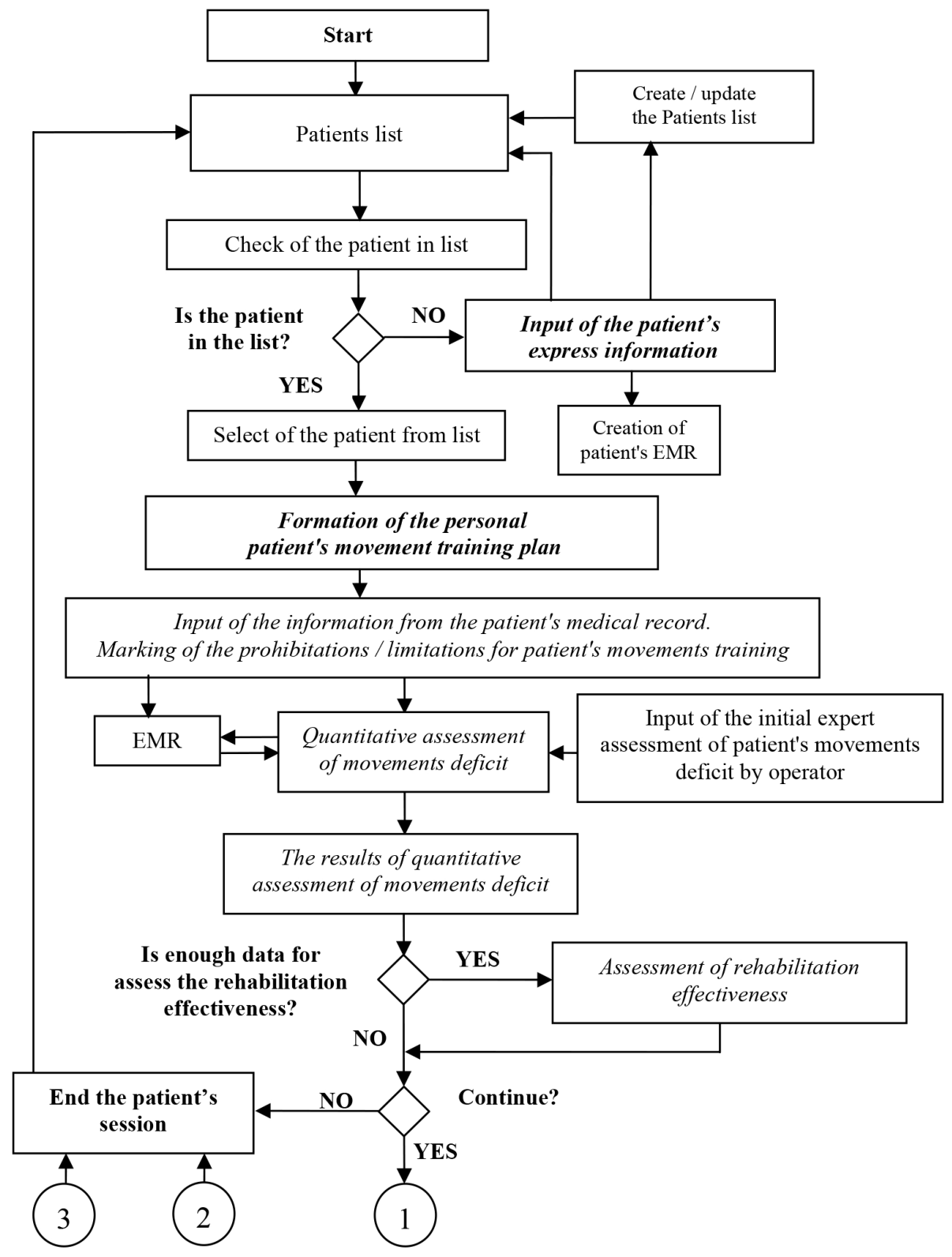

Fig. 2a. Algorithm for forming a personal movement rehabilitation plan: description of the patient's general state, assessment of movement deficit and rehabilitation effectiveness

Forming the patient's personal movements' rehabilitation plan begins with input of the information by the operator from the patient's medical record: neurological status, emotional state, concomitant diseases, as well as marking the prohibitation / limitation factors of movements training. The information is recorded in the patient's EMR. 


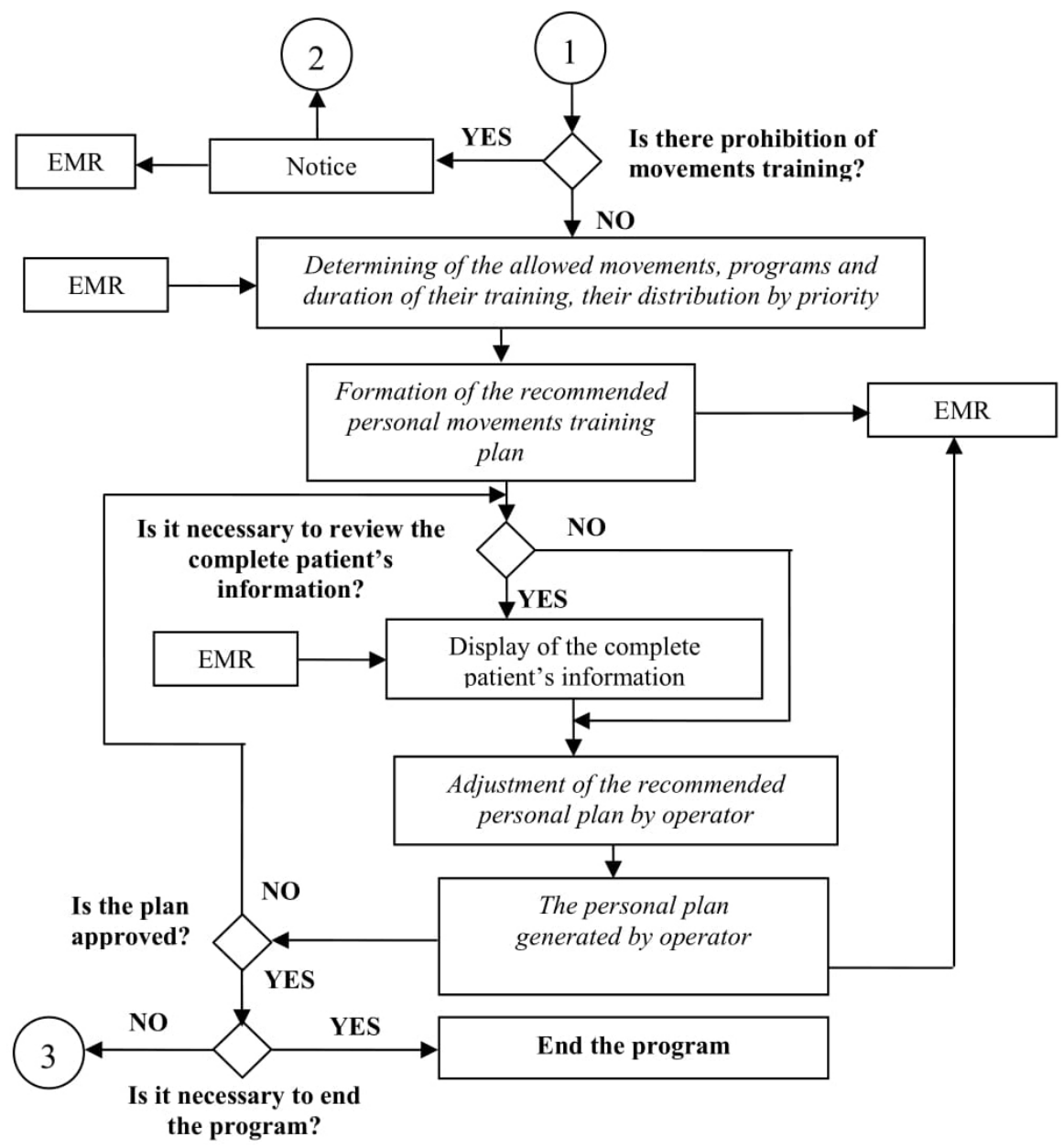

Fig. 2b. Algorithm for forming a personal movement rehabilitation plan: recommended and finally generated by operator plans

The next step is the movement deficit diagnostics. The operator inputs the initial expert assessment of movement deficit of patient's upper and lower limbs' selected departments at joints level, hand and walking. The program calculates and displays the results of quantitative assessment of movement deficit to the operator. The obtained information is recorded in the patient's EMR.

The rehabilitation effectiveness is quantitatively assessed at the end of patient's rehabilitation course. The operator is provided with quantitative and verbal characteristics of efficiency.

The patient session ends if only a quantitative assessment of movement deficit is required.

In case of forming the personal movements' rehabilitation plan there is a check of the permission / limitations / prohibition to perform the trainings based on prohibition / limitation factors of movements' trainings. If there is a movement training prohibition, the patient session ends, the operator is given the prohibition notice, which is recorded in the patient's EMR. 
Forming the personal movements rehabilitation plan continues in case of training permission. The recommended personal movements' rehabilitation plan — permitted movements, methods, programs and movement training duration, which are distributed by priority, is output to the operator. This plan is recorded in the patient's EMR.

The operator after reviewing the plan adjusts it by marking the concrete movements, methods, programs and movement training duration. At the same time, operator's choice is based on complete information on the patient, which he can view optionally. The personal plan generated by the operator is also recorded in the patient's EMR and is displayed to the operator in the text file form. If the operator doesn't approve this plan, it is possible to correct it with rewriting in the patient's EMR. Finally the patient's personal movements training plan generated by the operator is that plan, according to which the movements are trained at this rehabilitation stage.

Then the operator either ends the session with the current patient or ends the program.

The patient's rehabilitation course ends with a diagnostics - the quantitative assessment of rehabilitated movements deficit with the rehabilitation effectiveness assessment.

It should be noted that the formed personal movements training plan at a certain rehabilitation stage needs to be updated at the following stages.

\section{CONCIUSIONS}

Theoretical and practical bases of synthesis of information technology for forming a personal movement rehabilitation plan for patients after a stroke have been developed. The information technology is implemented by the specialized tool of digital medicine - software module "MovementRehabStroke 1.0".

This module consists of a graphical interface and basic information modules: Database, Module "MovementTestStroke 1.1" for quantitative assessment of movement deficit and Module for forming the personal movement training plan. The software implementation of modules of both the "MovementRehabStroke 1.0" and "MovementTestStroke 1.1" is the Microsoft Visual Studio 2013 environment, C\# programming language. They are installed in the PC structure.

The information module for quantitative assessment of movements deficit "MovementTestStroke 1.1" implements in an interactive mode a complete computational research algorithm of motor dysfunctions after a stroke. It provides the operator with distributed and integrated quantitative assessment of deficit of limb movements, their departments, fine motor hand, walking, muscle tone on the main and additional evidence criteria. The proposed approach in digital format provides an opportunity to perform the in-depth analysis, identify the disorders specificity for forming the personal rehabilitation plan, secondary prevention of disorders, rehabilitation effectiveness assessment.

The module operation is verified in clinical settings (23 patients after ischemic stroke). Expanding the range of additional evidence-based criteria for fine motor hand function assessing — the hand's fingers extension is important both for formation of the personal training plan and for assessing the recovery of fine motor hand, which is associated with speech restoration. 
The recommended personal rehabilitation plan by priority of its components (methods, programs, movements and their training duration) provides the operator with information and consulting support in formation (determination) of the personal movement training plan, which most effectively activates additional reserves of the organism to restore the movements, affected by pathology, at a certain rehabilitation stage and doesn't harm the general patient's condition.

Storing the complete patient's information - information from the patient's medical record and specialized information (quantitative assessment of movements deficit, movements' restoration personal plans - recommended and generated by the operator) - in the personal electronic medical record provides an opportunity to assess the rehabilitation effectiveness and its in-depth analysis.

The movements training personal plan needs to be regularly updated at various rehabilitation stages for the purpose of maximum or full restoration of motor and speech functions. The speech restoration in case of motor or motor-sensory aphasia is dependent on training and restoration of affected fine motor hand.

The obtained results will contribute to the creation of a new class of mobile means of digital medicine, installed in the structure of the smartphones for movements' assessment after a stroke, forming the personal rehabilitation plan and assessment of rehabilitation results.

\section{REFERENCES}

1. Truelsen T. et.al. Stroke incidence and prevalence in Europe: a review of available data. Eur. J. Neurol. 2006, № 13, pp. 581-598. Doi: 10.1111/j.1468-1331.2006.01138.x

2. Vovk M.I., Kutsiak O.A., Lauta A.D., Ovcharenko M.A. Information Support of Researches on the Dynamics of Movement Restoration After the Stroke. Cybernetics and Computer Engineering. 2017, № 3 (189), pp. 61-78. (in Ukrainian)

3. Vovk M.I., Kutsyak O.A. Software module for personal diagnostics of motor functions after stroke. Cybernetics and Computer Engineering. 2019, № 4 (198), pp. 62-77.

4. Certificate of registration the copyright "Computer program «Diagnostics of deficit of general limb movement, fine motor hand, walking form by the technique for quantitative assessment of movements deficit in patients after a stroke "MovementTestStroke 1.0 (PC)"»" / M.I. Vovk, O.A. Kutsiak (Ukraine); No. 98161; published dated 16.06.2020 [in Ukrainian].

5. Belova A., Shchepetova O. Scales, tests and questionnaires in medical rehabilitation. Moscow: Antidor, 2002, 440 p. (in Russian)

6. Smychek V., Ponomareva E. Craniocerebral trauma (clinic, treatment, examination, rehabilitation). Minsk: Research Institute of ME and R, 2010, 430 p. (in Russian)

7. Vovk, M.I., Halian, Ye.B., Kutsiak, O.A., Lauta, A.D. (2018). Formation of Individual Complex of Control Actions for Motor and Speech Rehabilitation after a Stroke. Kibernetika i vyčislitelnaâ tehnika. 2018, № 3 (193), pp. 43-63. [in Ukrainian].

8. Vovk, M.I., Halian, Ye.B., Kutsiak, O.A. Computer Software \& Hardware Complex for Personal Oral Speech Restoration after a Stroke. Sci. innov. 2020, Vol. 16, № 1(91), pp. 54-68. URL: https://doi.org/10.15407/scine16.01.054

9. Cramer S.C. A functional mri study of subjects recovered from hemiparetic stroke. Stroke. 1997, № 28, pp. 2518-2527. Doi: 10.1161/01.STR.28.12.2518

Received 05.05.2020 


\section{ЛІТЕРАТУРА}

1. Truelsen T. et.al. Stroke incidence and prevalence in Europe: a review of available data. Eur. J. Neurol. 2006. № 13. P. 581-598. Doi: 10.1111/j.1468-1331.2006.01138.x

2. Вовк М.І., Куцяк О.А., Лаута А.Д., Овчаренко М.А. Інформаційний супровід досліджень динаміки відновлення рухів після інсульту. Кибернетика и вычислительная техника. 2017. №3 (189). С. 61-78

3. Vovk M.I., Kutsyak O.A. Software module for personal diagnostics of motor functions after stroke. Cybernetics and Computer Engineering. 2019. № 4 (198). P. 62-77.

4. Свідоцтво про реєстрацію авторського права на твір. «Комп’ютерна програма «Діагностика дефіциту загальних рухів кінцівок, тонкої моторики кисті, форми ходи за методикою кількісного оцінювання дефіциту рухових функцій у пацієнтів після інсульту “MovementTestStroke 1.0 (РС)"»/ M.І. Вовк, О.А. Куцяк (Україна); № 98161 опубл. від 16.06.2020.

5. Белова А., Щепетова О. Шкалы, тесты и опросники в медицинской реабилитации. М.: Антидор, 2002. $440 \mathrm{c}$.

6. Смычек В., Пономарева Е. Черепно-мозговая травма (клиника, лечение, экспертиза, реабилитация). Мн.: НИИ МЭ и Р, 2010. 430 с.

7. Вовк М.І., Галян Є.Б., Куцяк О.А. Лаута А.Д. Формування індивідуального комплексу керувальних впливів для реабілітації рухів і мовлення після інсульту. Кибернетика и вычислительная техника. 2018. № 3 (193). С. 43-63.

8. Vovk, M.I., Halian, Ye.B., Kutsiak, O.A. Computer Software \& Hardware Complex for Personal Oral Speech Restoration after a Stroke. Sci. innov. 2020. Vol. 16. № 1(91). P. 54-68. URL: https://doi.org/10.15407/scine16.01.054

9. Cramer et. al. A functional mri study of subjects recovered from hemiparetic stroke. Stroke. 1997. № 28. P. 2518-2527. Doi: 10.1161/01.STR.28.12.2518

Отримано 05.05.2020

Вовк M.І., канд. біол. наук, старш. наук. співроб.,

зав. відд. біоелектричного керування та медичної кібернетики

e-mail: vovk@irtc.org.ua; imvovk3940@gmail.com

Куцяк О.А., канд. техн. наук,

старш. наук. співроб., відд. біоелектричного керування

та медичної кібернетики

e-mail: spirotech85@ukr.net

Міжнародний науково-навчальний центр інформаційних технологій

та систем НАН України та МОН України,

пр. Акад. Глушкова, 40, м. Київ, 03187, Україна

\section{ІНФОРМАЦІЙНА ТЕХНОЛОГІЯ ФОРМУВАННЯ ПЕРСОНАЛЬНОГО ПЛАНУ РЕАБІЛІТАЦІЇ РУХІВ ПІСЛЯ ІНСУЛЬТУ}

Bcmyn. Інсульт посідає друге місце у переліку головних чинників смерті і є провідною причиною інвалідності в Україні. Синтез інноваційних технологій, які сприяють відновленню порушених або втрачених внаслідок інсульту рухів - актуальне науковоприкладне завдання.

Meтою статmi є синтезування інформаційної технології формування персонального плану реабілітації рухів після інсульту на базі кількісного оцінювання їх дефіциту за доказовими критеріями.

Результати. Розроблено технологію інформаційного супроводження формування персонального плану тренувань рухів з метою їх відновлення після інсульту, яку реалізує спеціалізований програмний модуль «MovementRehabStroke 1.0» інформаційно-консультаційної допомоги лікарю у визначенні плану: рухи, методи (електроміостимуляція та / або біологічний зворотний зв'язок), програми, тривалість тренування. 
Розроблено структурно-функціональну модель взаємодії оператора (лікаря) 3 програмним модулем «MovementRehabStroke 1.0», який складається з графічного інтерфейсу та головних інформаційних модулів: Бази даних, Кількісного оцінювання дефіциту рухів «MovementTestStroke 1.1», Формування персонального плану тренування рухів. Інтерфейс забезпечує оператору діалоговий режим роботи з інформаційними модулями.

Розроблено алгоритм роботи спеціалізованого програмного модуля «MovementRehabStroke 1.0» у проведенні досліджень 3 формування персонального плану тренувань рухів пацієнта за показниками кількісного оцінювання дефіциту рухів, які надає інформаційний модуль «MovementTestStroke 1.1», та інформації, що надходить 3 персонального електронного медичного запису (ЕМ3) пацієнта: показники неврологічного статусу, супутні захворювання тощо.

Висновки. Отримані результати сприятимуть створенню нового класу мобільних засобів цифрової медицини - мобільних застосунків у структурі сучасних смартфонів для діагностики рухів після інсульту, формування персонального плану реабілітації, оцінювання іiї ефективності.

Ключові слова: інформаційна технологія, иифрова медицина, програмні модулі, інсульт, рухи, діагностика, реабілітація, персональний план, структурно-функиіональна модель, алгоритм, електростимуляція, біологічний зворотний зв'язок. 